\title{
GIS-Based Projected Land Use: A Case Study of Dhanbad District, Jharkhand, India
}

\author{
S.E. Saranaathan and S. Vaishaly ${ }^{1}$ \\ School of Civil Engineering, SASTRA University, Thanjavur-613 401, India \\ ${ }^{1}$ School of Ecology and Environment, Nalanda University, Rajgir-803 116, India \\ E-mail: esaranathan@yahoo.co.in
}

\begin{abstract}
Coal mining in the Dhanbad district has resulted in ecological imbalance in land degradation, deforestation, deterioration of soil, air and water pollution etc. There is a need to monitor and plan in the mining district. The present study mainly focuses on the use of remote sensing and GIS for sustainable land use. The multi-spectral and multi-temporal satellite imageries and corresponding to the survey of India toposheets $73 \mathrm{I}$ and $72 \mathrm{~L}$ were interpreted. Thematic maps like land use, geomorphology, soil, contour, slope, wasteland etc., were prepared after field and laboratory studies. Seven aspects of land use planning have been investigated viz. i) assessment of water potential zones, ii) identification of water recharge areas, iii) mapping the land degraded areas due to mining and soil erosion, iv) categorisation of agricultural water quality zones, v) classification of land capability and suitability classes, vi) wasteland development assessment, vii) evaluation of afforested and forest lands. Based on the above inferences, a comprehensive spatial model on the projected best land use of the Dhanbad district has been generated. As per the analysis, $24 \%$ of the land is suitable for the double-crop area, and $47 \%$ is the best for single and other crops. Among the $9 \%$ of Reserved Forest, about half of the land has been demarked suitable for forest plantation. Nearly $2 \%$ of the area is apt for rural/urban development, and $3 \%$ of the mining area could be reclaimed for grazing and horticultural development. The proposed model has a synchronising disposition with the regional land use outlook if implemented.
\end{abstract}

